\title{
Effectiveness of Monetary Policy and the Growth of Industrial Sector in China
}

\author{
Adebayo Augustine Kutu*, Ntokozo Patrick Nzimande, Simiso Msomi \\ School of Accounting, Economics \& Finance, University of KwaZulu-Natal, Westville Campus, South Africa \\ ade_kutu@yahoo.com*nzimanden3@ukzn.ac.za \& sssgmsomi@gmail.com
}

\begin{abstract}
China is viewed as the pillar of Emerging Market Economies (EMEs), deems to surpassed United State, and become the topmost industrialized country in the world with the prospects of major shift in the future world power. However, growth rate has slow down since the third quarter of 2014. Through this paper, we aim at investigating the impacts of monetary policy on industrial sector growth, and determine whether the long-run industrial sector growth in China can be foster by the effectiveness of monetary policy. It also examines the interrelationships among the variables employed and determines the steady-state relationships between industrial sector growth and monetary policy. Time-series econometric techniques such as unit roots, ARDL and ECM are employed to monthly data for the year 1994:1 to 2013:12.According to the empirical results derived, the effectiveness of monetary policy significantly affects industrial sector growth and the short-run impact of monetary policy on industrial output production is established.
\end{abstract}

Keywords: Monetary Policy, industrial sector Growth, ARDL Model

\section{Introduction}

The issue of how monetary policy affects industrial sector growth and stimulates output has been widely debated over the years. A major source of the debate is centered around the degree of impact the monetary policy has on the industrial sector in stimulating output growth. The debate has thus been does monetary policies have any impacts on industrial sector growth. While it is generally agreed upon that monetary policy impacts economic activities and industrial sector growth, others have different views on the extent to which the phenomenon occurs. This growing concern about how effective monetary policy is in affecting industrial sector growth rooted the researchers' desire to carry out an empirical investigation on the effectiveness of monetary policy and industrial sector growth in China. There is also the need to better understand the links between the monetary policy and the industrial sector growth. It is worthy to note that the monetary policy environment in China has been challenged over the years where the country has struggled to move to a more market oriented financial system (see Liao and Tapsoba, 2014). There has been instability in the recent past, with the economy being vulnerable to global shocks and competiveness from the United State (US) on which economy controls the global market. For example, the mounting problems on Chinese economy in which Exports, which have declined throughout the first quarter of 2015, fell again in July by $8.3 \%$. Imports were also down, dropping $8.1 \%$ in July from a year earlier, after a decline of $6.1 \%$ in June, pointing to a slowdown in demand from Chinese industries for raw materials. This led to a surprise move by the monetary authority to lower by $2 \%$ the value of its currency.

Historically, the China's monetary policy has in general implemented three major strategies since 1984 in order to stabilize the economy and achieve industrial sector growth. First, in 1984-1992, China's monetary policy was based on flexible and tight monetary policies; second, in 1993-1996, the monetary policies were some moderately tight monetary policies; thirdly, (1997-date), mature and judicious monetary policies have been implemented (see Zhou, 2015). The relationship between money supply, prices and economic growth shows different characteristics and some inbuilt mechanism through which industrial output is also stimulated under these three strategies. However, famous researchers in the field of monetary economics in China have tried through their studies to unravel those inbuilt mechanisms through which monetary authority stimulates the economy. Geiger (2008) focuses on instruments of monetary policy (interest rate and money supply) in China and their effectiveness in achieving economic growth target. Recently, Fernald et al. (2014) expanded on it and concentrated on monetary policy effectiveness in stabilizing economic activities in China. Liao and Tapsoba (2014) in the same vein looked at monetary policy and interest rate liberalization. They studied the stability of money demand function in the light of progress in financial sector reform that can stimulate economic growth. All these were just to mention a few of monetary researches on the effectiveness of monetary policy. However, a common feature of most of these studies is the fact that they were based on partial assessment to unravel the degree to which monetary policy can affects the economy. 
None of the study has focus on industrial sector, the fastest engine through which domestic prosperities can be achieved. This research work tends to focus on this and other issues relating to the effectiveness of monetary policy on the China's economy. Our understanding of how these monetary instruments (interest rate, exchange rate and money supply) and the control variable (prices) relate with our industrial sector growth will provide insights to whether or not the monetary policy can stimulate industrial output growth. It will further allow the study to unravel the inbuilt mechanism through which policy actions are formulated to guide against unstable monetary environment in the economy. Finally, it will also help in understanding the need for a stable exchange rate to curb the slow growth rate, exchange rate depreciation and other challenges that is currently seeing in the country.

\section{Literature Review}

The link between monetary policy and output growth has been widely discussed in the literature. IMF (2000), in one of its publications focuses on the need to determining the extent to which a nation's monetary policy affects her industrial output and affect economic growth. According to the publication, the effectiveness of monetary policy is vital to the achievement of economic stability in any nation. However, Sun (2013) asked; does monetary policy matter in China and does it affects industrial output growth? To answer this question, divergence views erupted. Gong and $\mathrm{Li}$ (2006) indicate that there exists a limited effect of monetary policy on industrial output and that the change in money supply is not associated with the change of price index in stimulating industrial output in China. Ping (2004) found evidence that there exists long-run monetary neutrality in China, and the margins of price fluctuation are proportionally associated with changes in money supply. In this regard, Uhlig (2005) concur and reveals that monetary policy has no clear effect on the GDP especially on the industrial output growth. In South Africa, Precious and Makhetha-Kosi (2014) share the same view and show that money supply, repo rate and exchange rate are insignificant monetary policy instruments that drive output growth. In addition, Kutu and Ngalawa (2016) further demonstrate that monetary authorities have very limited control over industrial output growth using instruments of monetary policy.

On the contrary, the finding of Fasanya et al. (2013) opposes what Precious and Makhetha-Kosi (2014) reveals in South Africa. Their study shows that inflation rate, exchange rate and external reserve are significant monetary policy instruments that drive industrial output growth. Muneer et al. (2011) and Dong (2012) found a relationship between monetary policy and economic development and that monetary policy plays an important role in the macro-economic control in China including industrial output growth. Similarly, Kutu et al. (2016) reveal that monetary policy (money supply) is observed to exert a significant positive impact on output growth in the short-run from about the eighth month. Liu et al. (2002) also provides an empirical support of the stable relationship between CPI and money supply in stimulating industrial output growth. The mechanism in such that an increase in money supplies will lower interest rate, low interest rate will increase the borrowing capacity of investors and increase investment and on timely, boost output production and stimulate industrial output production (growth).

Nevertheless, neither of the two contrary opinions mentioned above on the Chinese economic performance and the practice of monetary policy can be discarded, but established consensus of economists believe that monetary policy plays an important role on economic activities of a nation. For example, on the global happenings, Kim (1999) reveals that monetary policy matters and has significant effects on output in the short-run and that a proportion of output fluctuation in postwar G-7 is caused by monetary policy shocks. This view is also in line with Nagel and Parker (2003) that innovations (shocks) of any of the monetary policy variables have the potential for stimulating the economy and in particular, the industrial output. Chuku's (2009) study further highlights the effects of monetary policy shocks on output and prices on the Nigerian economy with the affirmation that monetary policy shocks have both real and nominal effects on economic parameters. His conclusion is that an innovation in the quantity-based money supply (M2) affects economic activities, and that monetary policy shocks have been a modest driver of the business cycle in Nigeria. Finally, Bernanke et al. (2005) are of the same mind that monetary policy is relevant and can impacts industrial output growth. According to them, monetary authorities are tasked with the duty of analysing thousands of variables in their decision-making process to determine how to respond to a shock in the economy. Their decision is usually well guided on price stability and output growth, hence, affects economic activities. Base 
on the forgoing, the debate on the effectiveness of monetary policy in stimulating industrial output in China need to be empirically studied and resolved.

\section{Methodology}

Achieving the study's objective will help answer the following research questions:

- Do monetary policies affect industrial output growth in China?

- Is there a stable relationship between industrial sector growth and the variables employed?

- Can the long-run industrial sector growth in China be foster by the impact of monetary policy?

- Is there a steady-state relationship between industrial sector growth and monetary policy?

From the standard growth equation, this study employs the endogenous growth model (AK model). The industrial output production is assumed to take the form of production function because the first version of the endogenous growth model (AK model) takes its root from the Cobb-Douglas production where the steady state (convergence theory) is established (see Muneer \& Rehman, 2012). Therefore, from the industrial output growth equation, we derive the estimable form using a Cobb-Douglas specification as follows:

$$
Y_{t}=A K_{t}^{a} L_{t}^{b}, 0<a<1,0<b<1,
$$

where $Y_{t}, K_{t}$ and $L_{t}$ are output, capital, and labor, respectively, and $A$ is a total or technology factor productivity (TFP). It further signifies other factors not captured by labor and capital, and sometimes refer as an unconventional input. As employed in this study, we assume TFP is a function of interest rates (IN), exchange rates (EX), money supply (MS) and inflation (IF) over a given period of time $t$ which is specified as:

$$
A_{t}=f\left(I N_{t}, E X_{t}, M S_{t}, I F_{t}\right)
$$

Therefore, substituting $A_{t}$ in equation (2) into equation (1), we get a new extended Cobb-Douglass production function given by:

$$
Y_{t}=I N_{t}^{\alpha 1} E X_{t}^{\alpha 2} M S_{t}^{\alpha 3} I F_{t}^{\alpha 4} K_{t}^{a} L_{t}^{b}, 0<a<1,0<b<1,
$$

Following Omar and Hussin (2015:102), we linearize and take logs of the equation (3) given as:

$$
\log Y_{t}=\alpha_{0}+\alpha_{1} \log I N_{t}+\alpha_{2} \log E X_{t}+\alpha_{3} \log M S_{t}+\alpha_{4} \log I F_{t}+a \log K_{t}+b \log L_{t}+\varepsilon_{t} \text {, }
$$

Note that interest rate (IN) is in its natural log and does not necessarily re-logged. Equation (4) above characterizes our industrial output growth model for the Chinese economy where $Y_{t}$ is viewed as industrial output production that captures the industrial sector contribution to GDP. Our industrial output production $(I P)$ can be substituted into the equation as:

$$
\log I P_{t}=\alpha_{0}+\alpha_{1} \log I N_{t}+\alpha_{2} \log E X_{t}+\alpha_{3} \log M S_{t}+\alpha_{4} \log I F_{t}+a \log K_{t}+b \log L_{t}+\varepsilon_{t}
$$

Where $I P_{t}$ is a proxy of $Y_{t}$ to capture industrial output production; $\alpha_{o}$ is constant; $\beta_{1} \log I N_{t}+\beta_{2} \log E X_{t}+$ $\beta_{3} \log M S_{t}+\beta_{4} \log I F_{t}$ capture $\log A(\mathrm{TFP})$ that are not captured by labor and capital; $a \log K_{t}$ and $b \log L_{t}$ are capital and labor respectively and $\varepsilon_{t}$ is the error term.

However, to model data appropriately and extract both long-run and short-run relationships in achieving the study's objective, we take into account the existence of unit roots and cointegration associated with the data to determine the appropriate methodology. To achieve this, Giles (2013) enumerates four guides to choose an appropriate methodology; firstly, when all of the series are stationary at I(0), in this case, an Ordinary Least Square (OLS) estimation is appropriate. Secondly, when all the series are integrated of the same order (e.g., I(1)), but they are not cointegrated. In this case, Vector Autoregressive (VAR) estimation in first differences involving no long-run estimation is very suitable. Thirdly, when all series are integrated of the same order, and are also cointegrated, in this case, there are two types of regression models that can be estimated: (i) An OLS regression model using the levels of the data (Johansen's method). This will provide the long-run equilibrium relationships between the variables. (ii) An Error Correction Model (ECM), estimated by OLS. This model will represent the short-run dynamics of the relationship between the variables. Finally, in a more complicated situation where some of the variables in question are stationary at levels I(0) and some are I(1) 
or even fractionally integrated leading to no clear cut in the three situations noted above. This situation is particular to series employ in this study and hence, forms the bases of the adoption of the advance methodology of Pesaran et al. (2001) Autoregressive Distributed Lag (ARDL) model that is most suitable.

Estimating Technique: The estimating technique adopted in this study is the ARDL approach of Pesaran et al. (2001) to test for existence of long-run and short-run relationship between the industrial output production and monetary policy using industrial production data, monetary variables and control variable. The choice of the ARDL methodology for this study is based on a number of features that give it some advantages over conventional cointegration testing. For instance:

- It is the most recent estimation technique to estimate long-run and short-run dynamics (Giles, 2013).

- It can be used with a mixture of I(0) and I(1) data: This means that this approach can be applied to sequence whether they are I(0), I(1), mutually co-integrated, or irrespective of their order of integration but not I(2) (Sari et al., 2008 and Katircioglu, 2009).

- It allows different variables to be assigned different lags in the model (Giles, 2013).

- It can accommodate more than two lags and up to six variables (Giles, 2013).

- It allows the short-run and long-run of the model to be estimated simultaneously (Dritsakis, 2011).

- It is good for both small and large sample size (see Narayan, 2005; and Rafindadi and Yosuf, 2013).

- Lastly, it involves just a single-equation set-up, making it simple to implement and interpret (Giles, 2013).

In line with the above justification for the choice of the estimation technique, the ARDL further enables this study to conduct empirical comparison and determine the fundamental factors the monetary policy has on the growth of industrial sector (output) in the short-run and in the long-run and also establish the bond testing approach to cointegration for the Chinese economy. Therefore, equation (5) can be simplified into a basic ARDL regression model in a matrix form to capture the Chinese economy given as:

$$
\begin{aligned}
& \Delta I P_{t}=\beta_{0}+\sum_{j=1}^{n} \beta_{1} \Delta I P_{t-1}+\sum_{1=0}^{n} \beta_{2} \Delta E X_{t-1}+\sum_{1=0}^{n} \beta_{3} \Delta I F_{t-1}+\sum_{1=0}^{n} \beta_{4} \Delta I N_{t-1}+\sum_{1=0}^{n} \beta_{5} \Delta M S_{t-1}+ \\
& \alpha_{1} I P_{t-1}+\alpha_{2} E X_{t-1}+\alpha_{3} I F_{t-1}+\alpha_{4} I N_{t-1}+\alpha_{5} M S_{t-1}+\varepsilon_{t}
\end{aligned}
$$

where $I P_{t}$ is a $(5 \times 1)$ vector of endogenous variables capturing industrial production; $\beta_{o}$ is a $(5 \times 1)$ vector of constant components; $\Delta$ denotes the first difference operator; $I P_{t-1}, E X_{t-1}, I F_{t-1}, I N_{t-1}$ and $M S_{t-1}$ are lagged endogenous variables; $\beta_{1}-\beta_{5}$ represent short-run dynamics of the model; $\alpha_{1}-\alpha_{5}$ correspond to the longrun relationship, and $\varepsilon_{t}$ is a (5x1) vector of random disturbance term (error term). As earlier stated, all variables are in their logarithm form except the interest rate that is on its natural log.

Furthermore, the ARDL method estimates $(n+1)^{k}$ number of regressions in order to obtain the optimal lag length for each variable, where $\mathrm{p}$ is the maximum number of lags to be used and $\mathrm{k}$ is the number of variables in the equation. The appropriate lag selection is based on the Akaike Information Criterion (AIC) and Schwarz Information Criterion (SIC) as popularly used in the literature (see Pesaran et al., 2001; Dritsakis et al., 2011 and Saibu and Apanisile, 2013). In line with the above model in equation (6), there are five steps to carry out ARDL estimation: the ARDL Unit Root Testing, the ARDL Lag Lengths Determination, the ARDL Regression, and the ARDL Bond Testing for Cointegration and the ARDL Error Correction Model (ECM).

The ARDL Unit Root Testing: As a pre-condition for cointegration analysis, this study estimate time series data to test the unit root hypothesis. What then is unit root? A unit root is a process that evolves through time that can cause problems in statistical inference involving time series models. According to Omolade et al. (2013), a unit root implies that the time series under scrutiny is non-stationary while the absence of a unit root means that the stochastic process is stationary. To determine the order of series, we follow Sari et al. (2008) and conduct six different unit root tests. We conduct the tests using the augmented Dickey and Fuller (ADF), Dickey-Fuller test, Phillips and Perron (PP), Elliot test, Kwiatkowski (KPSS) test and Ng and Perron (2001). All tests produced similar results. However, for us to preserve space, we report the robust version of Augmented Dickey-Fuller Test (ADF) and Phillips and Perron (PP) at the individual intercept and the individual intercept plus trend. The unit root null hypotheses tested for the ADF and PP are:

- $\quad H 0: \alpha=1$, the series is non-stationary.

- $H 1: \alpha \neq 1$, the series is stationary. 
According to Pesaran et al. (2001), the ARDL approach is applicable irrespective of whether underlying variables are purely I(0), I(1) or mutually co-integrated. However, they further revealed that the dependent variable must be I(1) and the independent variables I(0) or I(1) (see Kouakou, 2011:5).

The ARDL Lag Lengths Determination: One of the advantages of ARDL is that different variables can be assign different lags as they enter the model (Giles, 2013). The lag length gives an indication of the time to which monetary policy action to promote industrial sector growth is implemented. According to Ali et al. (2008), the order of lag selection criteria for ARDL model is usually obtained from an unrestricted VAR by the use of SIC and AIC that selects the lowest value in the overall model. The benchmarks is that, the lower the value of the SIC and AIC, the better the model.

The ARDL Regression: In econometrics, regression analysis is a statistical process for estimating the relationships among variables. It involves many techniques for modeling and analyzing several variables when the focus is on the relationship between a dependent variable and one or more independent variables. The ARDL regression model has been used in most recent times and has been more valuable vehicle for testing for the presence of long-run and short-run relationships between economic time-series. The models can be used to test for cointegration, and estimate long-run and short-run dynamics, even when the variables in question may include a mixture of I(0) or I(1) data (Pesaran et al., 2001).

The ARDL Bond Testing for Cointegration: Following the empirical literature of Ozturk and Acaravci (2013), a long-run cointegration relationship between industrial output productions and the variables employed for the ARDL estimation is carried out. What then is Cointegration? Cointegration is defined when the error term in the regression modeling is stationary. This theory was developed in the late 1980s as a statistical property of time series variables where two or more-time series are cointegrated and share a common stochastic drift (variables in the regression equation move together, e.g., they do not drift apart over time). Robinson and Marinucci (2003) reaffirmed that time series econometrician has developed cointegration techniques and generated much applied interest to be used for non-linear time series data. The testing for cointegration using Johansen cointegration test and Erik and Pär (2007) prevents the regression of non-stationary variables on other thereby avoiding results that are entirely spurious or spuriously correlated. Based on literature, there are three leading methods of testing for cointegration: The Engle-Granger two-step method, the Johansen test method and the Phillips-Ouliaris cointegration test method. However, before a time series data can be consider for cointegration, it must satisfy the condition of been integrated in the same order (first-order I(1)) and form a linear stationary combination. If residuals are in I(1), one cannot use the estimated standard errors and the associated t-values of the estimated coefficients (Gujarati, 2004), but a model containing only first differences I(1) should be estimated (Brooks, 2002). However, the ARDL model relaxes all the conditions of the conventional (Engle-Granger two-step method, Johansen test method and the Phillips-Ouliaris) cointegration test assumptions and hence, can accommodate a mixture of I(0) and I(1) variables.

The ARDL Error Correction Model: A cointegrated variable needs an Error Correction Mechanism (ECM) that must be incorporated into the regression model. The ECMs are a category of multiple time series models that directly estimate the speed at which a dependent variable $(Y)$ returns to equilibrium after a change in independent variable (X). More so, the ECM is a theoretically driven approach useful for estimating shortterm and long-term dynamic effects of one variable on another. In line with Saibu and Apanisile (2013), all coefficients of the short-run equation are coefficients relating to the short-run dynamics of the model's convergence to equilibrium and further contain the speed of adjustment that is employ in the ARDL estimation of this study.

Brief Definition of variables: In line with Omoniyi and Olawale (2015), we examine monthly data for China's economy over the period of 1994:1 to 2013:12 to determine the impacts of monetary policy on industrial output production. The variables employ for the model are based on literatures and can be briefly define as follows. 
The Dependent variable: the industrial sector (IP) contribution to GDP is the dependent variable, this is the total volume of goods and services produced and are proxy by manufacturing sector contribution to GDP as employed by Naudé et al. (2015).

The Independent variables: these are monetary variables and control variable as shown below.

- The monetary variables are policy variables usually employed by monetary authorities to achieve a certain goal. These variables are: the interest rates (IN), exchange rates (EX) and money supply (MS). The exchange rate is treated as a monetary variable since it is under the control of monetary authority in China (operating managed floating exchange rate system). All these variables are in line with Ncube and Ndou's (2011) study.

- Control variable is Consumer Price Index (CPI) that is proxy to captured inflation rates (IF) in the economy, which is in line with Ngalawa and Viegi (2011). Control variable strongly influences values and are determined by market behavior since inflation (prices) determine the total output produced.

Source of Data: The data employed in this paper are monthly time series data from 1994 to 2013. All data are sourced from the statistical database of the Central Bank of China (CBC), International Monetary Fund (IMF), International Financial Statistics (IFS), World Bank's World Development Indicators (WDI) and the Organization for Economic Co-operation and Development (OECD). All variables are in 2010 base year. They were also transformed to log except interest rate that was already in its natural log so that they have same magnitude and to improve the data analysis.

\section{Results}

This section deals with various analytical tests. We begin by testing for unit roots (stationarity of the data). In addition, there is a test for the ARDL lag determination. A test is also conducted to measure the strength of the model selection. The study also carries out a diagnostic test before embarking on the cointegration test.

The ARDL Unit Root Test: This study tests for the presence of unit roots using a robust version of Augmented Dickey-Fuller Test (ADF) and Philips-Perron test at the individual intercept and the individual intercept plus trend. The testing using these approaches are to compare and validate the results and further ensure consistency (See Moon and Perron, 2004; Demetriades and Fielding, 2012; Ishibashi, 2012 and Frimpong, 2012). As shown in Tables 1 and 2, these tests are conducted under the null hypothesis $\left(H_{0}: \alpha=\right.$ $1)$, variable is non-stationary (that is, there is unit root) as opposed to the alternative hypothesis $\left(H_{1}: \alpha \neq 1\right)$ of stationarity (no unit root). The aim here is to establish that no variable is I(2) as suggested by Pesaran et al. (2001). Base 0n the test, two of the variables are I(0) while others are I(1) and none is in I(2). The P-Values are shown at $1 \%, 5 \%$ and $10 \%$, which show that all the variables are statistically significant and stationary (has no unit roots). This satisfies Pesaran et al. (2001) that the dependent variable must be I(1) and the independent variables I( 0$)$ or I(1).

Table 1: ADF unit root tests

\begin{tabular}{|c|c|c|c|c|c|c|}
\hline \multirow[t]{2}{*}{ Variables } & \multicolumn{3}{|c|}{$\begin{array}{l}\text { ADF Unit root-test (individual } \\
\text { intercept) }\end{array}$} & \multicolumn{3}{|c|}{$\begin{array}{l}\text { ADF Unit root-test (individual intercept and } \\
\text { trend) }\end{array}$} \\
\hline & $\begin{array}{c}\text { Order of } \\
\text { integration }\end{array}$ & $\begin{array}{c}\mathbf{t}^{*} \\
\text { Statistics }\end{array}$ & P-Value & $\begin{array}{c}\text { Order of } \\
\text { integration }\end{array}$ & $\mathbf{t}^{*}$ Statistics & P-Value \\
\hline IP & $\mathrm{I}(1)$ & 151.640 & $0.0000^{* * *}$ & $\mathrm{I}(1)$ & 127.601 & $0.0000^{* * *}$ \\
\hline EX & $\mathrm{I}(0)$ & 361.007 & $0.0000^{* * *}$ & $\mathrm{I}(0)$ & 346.251 & $0.0000^{* * *}$ \\
\hline IF & I(1) & 197.042 & $0.0000^{* * *}$ & I(1) & 159.730 & $0.0000^{* * *}$ \\
\hline IN & $\mathrm{I}(0)$ & 40.8427 & $0.0000^{* * *}$ & $\mathrm{I}(0)$ & 59.9770 & $0.0000^{* * *}$ \\
\hline MS & $\mathrm{I}(1)$ & 289.576 & $0.0000^{* * *}$ & $\mathrm{I}(1)$ & 251.973 & $0.0000^{* * *}$ \\
\hline
\end{tabular}

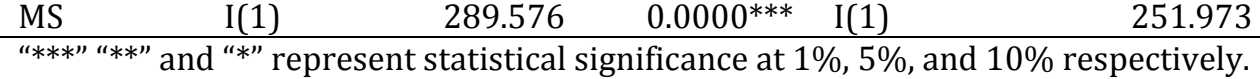


Journal of Economics and Behavioral Studies (ISSN: 2220-6140)

Vol. 9, No. 3, pp. 46-59, June 2017

Table 2: PP unit root tests

\begin{tabular}{|c|c|c|c|c|c|c|}
\hline \multirow[t]{2}{*}{ Variable } & \multirow{2}{*}{$\begin{array}{l}\text { PP Unit } \\
\text { intercept) } \\
\text { Order of } \\
\text { integration }\end{array}$} & \multirow{2}{*}{$\begin{array}{c}\text { root-test } \\
\text { t* Statistics }\end{array}$} & \multirow{2}{*}{$\begin{array}{c}\text { (individual } \\
\text { P Value }\end{array}$} & \multicolumn{3}{|c|}{$\begin{array}{l}\text { PP Unit root-test (individual intercept and } \\
\text { trend) }\end{array}$} \\
\hline & & & & $\begin{array}{l}\text { Order of } \\
\text { integration }\end{array}$ & $\mathrm{t}^{*}$ Statistics & P-Value \\
\hline IP & $\mathrm{I}(1)$ & 468.942 & $0.0000^{* * *}$ & $\mathrm{I}(1)$ & 460.835 & $0.0000^{* * *}$ \\
\hline EX & $\mathrm{I}(0)$ & 344.903 & $0.0000^{* * *}$ & $\mathrm{I}(0)$ & 326.665 & $0.0000^{* * *}$ \\
\hline IF & $\mathrm{I}(1)$ & 268.564 & $0.0000^{* * *}$ & $\mathrm{I}(1)$ & 352.520 & $0.0000^{* * *}$ \\
\hline IN & $\mathrm{I}(0)$ & 26.3052 & $0.0034^{* * *}$ & $\mathrm{I}(0)$ & 38.6539 & $0.0000^{* * *}$ \\
\hline MS & I(1) & 217.336 & $0.0000^{* * *}$ & I(1) & 160.643 & $0.0000^{* * *}$ \\
\hline
\end{tabular}

The ARDL Lag Determination: The orders of lags are selected using the Schwarz Information Criterion (SIC) and Akaike Information Criterion (AIC) that are commonly used in literature of ARDL estimation (see Pesaran et al., 2001 and Ozturk and Acaravci, 2011).

Table 3: The Panel ARDL Lags Selection Criteria

\begin{tabular}{lll}
\hline Serial number & Variables & Lag selections \\
\hline 1 & Industrial Production (IP) & 4 \\
2 & Exchange Rates (EX) & 1 \\
3 & Inflation Rates (IF) & 0 \\
4 & Interest Rates (IN) & 2 \\
5 & Money Supply (MS) & 1 \\
\hline
\end{tabular}

As shown in Table 3, the results show 4-lags for Industrial Production (IP), 1-lag for Exchange Rates (EX), 0lag for Inflation Rates (IF), 2-lags for Interest Rates (IN) and 1-lag for Money Supply (MS). These lags are obtained on each I(0) and I(1) variables (as revealed by the unit root tests) in line with Dritsakis (2011). More so, the study further allows an automatic lag selection dynamic regressor to choose an optimum lag for the model. This is done by carrying out a statistical unrestricted likelihood ratio test using the minimum criteria for the value of SIC and AIC. The study found the most appropriate automatic lag length selection for the entire model to be 4 as shown in Table 4. The 4-lags for the ARDL model is consistent with Christiano et al. (1996) and Sharifi-Renani (2010). Furthermore, the comparison between the SIC and AIC for the optimum 4-lags (-7.550924* and -7.685606*) selected shows that the AIC gives the lowest value (most negative), hence, adopted for the ARDL regression.

Table 4: The ARDL Optimum Lag Selection Criteria

\begin{tabular}{lll}
\hline Lag lengths & SIC & AIC \\
\hline 2 & -7.525843 & -7.671150 \\
3 & -7.475190 & -7.569456 \\
4 & $-7.550924^{*}$ & $-7.685606^{*}$ \\
5 & -7.489073 & -7.675214 \\
\hline
\end{tabular}

Measuring the Strength of the Lag Selection: In order to determine the strength of the Akaike Information Criterion (AIC) model selection criteria over the Schwarz criterion in the regression and also determining the long-run and short-run relationships in this study, we employ the criteria graph to determine the top twenty (20) different ARDL models. Based on the benchmark analysis for the model, "the lower the value of the AIC, thus the better the model". As shown in figure 1, the first ARDL $(4,1,0,1,2)$ model appears to be strongly preferred over the others as it gives the lowest (most negative) value of the Akaike Information Criterion. In addition, the ARDL $(4,1,0,1,1)$ and $(4,1,0,0,1)$ models appear to be the top second and third respectively as they record -10.256 and -10.254 values as indicated by their own criteria graph. 
Figure 1: The Strength of the Model Selection Summary

Akaike Information Criteria (top 20 models)

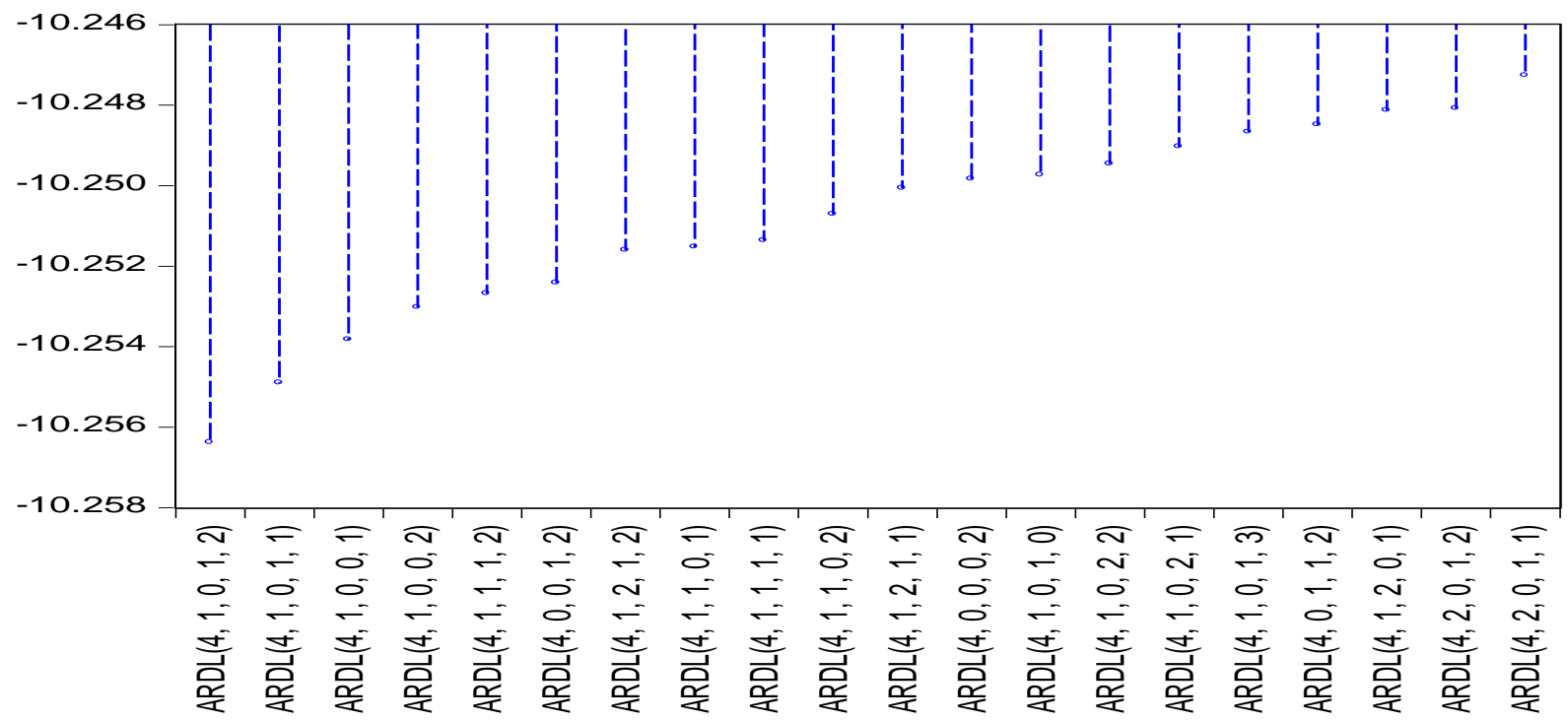

Diagnostic Tests: Since the model with 4-lags is chosen to be the best model, this study tests the model against serial correlation, heteroskedasticity and stability. The benchmark hypotheses that are tested are:

- $H_{0}: \alpha=1$, no serial correlation, no heteroskedasticity and no stability in the model

- $H_{1}: \alpha \neq 1$, there is serial correlation, heteroskedasticity and stability in the model

The result in Table 6 shows that there is no serial correlation (similarity between observations) in the model. In addition, Table 7 reveals that the model is free from heteroskedasticity (a process in which the variability of a variable is unequal across the range of values that are predicted). These results have shown that our model is consistent and favorable in analyzing the effectiveness of monetary policy and industrial sector growth in China. Finally, figure 2 shows the stability test for the ARDL model. Stability test is the test to investigate the stability or instability of the estimated coefficients in the model. The Recursive Chow test suggests the benchmark ARDL be stable over the sample period. The graph shows the Cusum test for the model. Since the line capturing our data passes within the $5 \%$ confidence interval, it means that the model is stable.

Table 6: Serial Correlation LM Test

\begin{tabular}{|c|c|c|c|}
\hline \multicolumn{4}{|c|}{ Breusch-Godfrey Serial Correlation LM Test } \\
\hline F-statistic & 1.309156 & Prob. $F(2,220)$ & 0.2721 \\
\hline Obs*R-squared & 2.763939 & Prob. Chi-Square(2) & 0.2511 \\
\hline
\end{tabular}

Table 7: Heteroskedasticity Test

\begin{tabular}{|c|c|c|c|}
\hline \multicolumn{4}{|c|}{ Heteroskedasticity Test: Breusch-Pagan-Godfrey } \\
\hline F-statistic & 1.308578 & Prob. F(12,222) & 0.2147 \\
\hline Obs*R-squared & 15.52437 & Prob. Chi-Square(12) & 0.2140 \\
\hline
\end{tabular}




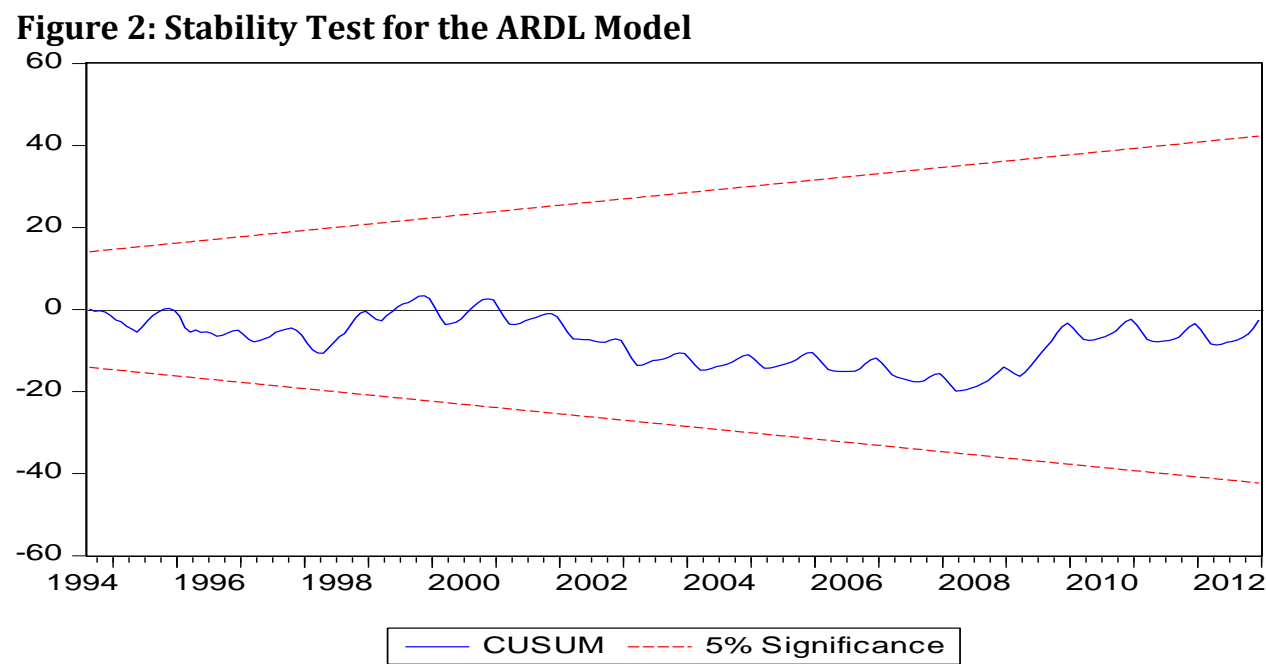

ARDL Regression Model: The estimation result is presented in Table 5. According to the estimates, all the variables in the model are statistically significant in explaining industrial output production. The result implies that monetary policy actions taken by monetary authority can impacts industrial output production in China. As expected, the interest rate is negative, indicating that an increase in the interest rates will lead to an unfavorable reduction in investment, thereby affecting industrial output production while an increase in money supply, prices and stable exchange rate will lead to an increase in industrial output production and thus, leads to an increase in economic growth. Conversely, currency appreciation EX(-1) reduces industrial output production and affects economic growth due to high technological cost as China is still a victim of technological importation. This relationship is in line with expectations, economic theory and empirical evidence (see Omolade and Ngalawa, 2014) that currency appreciation affects industrial output production owing to lower export (e.g. it causes trade deficit, which can exert a negative or contractionary effect on the economy). Overall, the finding has reveals that monetary policy is observed to exert a significant impact on industrial output production. This finding is in line with Liu et al. (2002), Fasanya et al. (2013), Dong (2012) and also similar to Kutu et al. (2016) that monetary policy plays an important role in the industrial output growth in China. Considering the results derived especially on the negative significant impact of the interest rates on industrial out production, policymakers should be conscious about their policy actions when pursing their mandate of price stability (fighting inflation). This is because sound economic policy is important for industrial output production in China while poor policy will result in a nexus of constraints from which escape may be difficult (or impossible). There should be policy consistence that will lead to stable interest rates in the economy.

The ARDL Bunds Testing for Cointegration: For robustness check, this study employs both bounds testing approach and Wald test to determine whether the variables have a cointegration relationship in our model when we have a group of time series, some of which are stationary at I(0) while others are at I(1). In the estimation result for the bounds testing approach, the F-statistic value of 5.517202 is bigger than the upper band (I1 Bound) at all levels. There is a significant and positive value of F-statistical value indicating a cointegration relationship among variables employed. In addition, the Wald tests result also confirms that all the variables have cointegration association. The F- statistics value of 9.71128 is greater than the Pesaran critical value at $5 \%$. This evidence reveals that we strongly reject the hypothesis of no cointegration relationship among the variables employed. 
Table 5: The ARDL Regression

Dependent Variable: DLOGIP

Method: ARDL

Maximum dependent lags: 4 (Automatic selection)

Model selection method: Akaike info criterion (AIC)

Dynamic regressors (4 lags, automatic): DLOGMS DLOGIF LOGEX IN

Selected Model: ARDL(4, 1, 0, 1, 2)

\begin{tabular}{lllll} 
Variable & Coefficient & Std. Error & t-Statistic & Prob.* \\
\hline DLOGIP(-1) & 0.305984 & 0.065467 & 4.673836 & 0.0000 \\
DLOGIP(-2) & 0.197632 & 0.066978 & 2.950705 & 0.0035 \\
DLOGIP(-3) & 0.172108 & 0.066505 & 2.587898 & 0.0103 \\
DLOGIP(-4) & 0.158273 & 0.065519 & 2.415690 & 0.0165 \\
DLOGMS & 0.002819 & 0.008759 & 0.321867 & 0.0419 \\
DLOGMS(-1) & 0.014789 & 0.008862 & 1.668945 & 0.0865 \\
DLOGIF & -0.006855 & 0.011469 & -0.597721 & 0.0506 \\
LOGEX & 0.076250 & 0.035638 & 2.139596 & 0.0335 \\
LOGEX(-1) & -0.057399 & 0.035269 & 1.627464 & -0.0051 \\
IN & -0.000119 & 0.000944 & 0.126359 & -0.0096 \\
IN(-1) & -0.002032 & 0.000971 & 2.093353 & -0.0375 \\
IN(-2) & -0.001451 & 0.000972 & 1.493081 & -0.0968 \\
C & 0.001172 & 0.000474 & 2.470975 & 0.0142 \\
\hline R-squared & 0.566779 & Mean dependent var & 0.008438 \\
Adjusted R-squared & 0.543361 & S.D. dependent var & 0.002066 \\
S.E. of regression & 0.001396 & Akaike info criterion & -10.25637 \\
Sum squared resid & 0.000433 & Schwarz criterion & -10.06499 \\
Log likelihood & 1218.124 & Hannan-Quinn criter. & -10.17922 \\
F-statistic & 24.20334 & Durbin-Watson stat & 2.009473 \\
Prob(F-statistic) & 0.000000 & & & \\
\hline
\end{tabular}

Table 8: The ARDL Bound Testing for Cointegration

ARDL Bounds Test

Included observations: 235

Null Hypothesis: No long-run relationships exist

\begin{tabular}{lll}
\hline Test Statistic & value & $\mathrm{k}$ \\
F-statistic & 5.517202 & 4 \\
Critical Value Bounds & & \\
Significance & I0 Bound & I1 Bound \\
$10 \%$ & 2.2 & 3.09 \\
$5 \%$ & 2.56 & 3.49 \\
$2.5 \%$ & 2.88 & 3.87 \\
$1 \%$ & 3.29 & 4.37 \\
\hline
\end{tabular}

Table 9: The ARDL Cointegration Testing

Wald Test

Equation: ARDL

\begin{tabular}{llll}
\hline Test Statistic & Value & $\mathrm{df}$ & Probability \\
F-statistic & 9.71128 & $(4,222)$ & 0.0000 \\
Chi-square & 26.38885 & 4 & 0.0000 \\
\hline
\end{tabular}

The Cointegration Graph: With the establishment of cointegration relationship among the variables employed, this study further employed the cointegration graphical form of the unrestricted ARDL to validate the above results and show the movement of the variables. Cointegration involves the co-movement of variables in a similar direction. For example, if there is a combination of two stationary variables in a 
regression model, then in general the linear combination of them will also be stationary; while the opposite is the case when two non-stationary variables are combined. However, if the two I(1) variables have an economic relationship, then they should move together such that the stochastic trends are similar (Brooks, 2002). As previously stated that ARDL model can accommodate a mixture of I(0) and I(1) variables. Figure 3 shows an unrestricted cointegration graph of the results of the model. It shows the cointegration results for the variables employ to determine the real effects of monetary policy on industrial sector growth in China. The graph looks stationary, because the fluctuation seems to revert to a "Mean" around zero. Overtime, the variable(s) in the model revert to its original value. Although some spikes were observed at some points in time, in particular 2006 and 2008. Nevertheless, the variables move together overtime until it reverts to zero.

\section{Figure 3: Cointegration Graph}

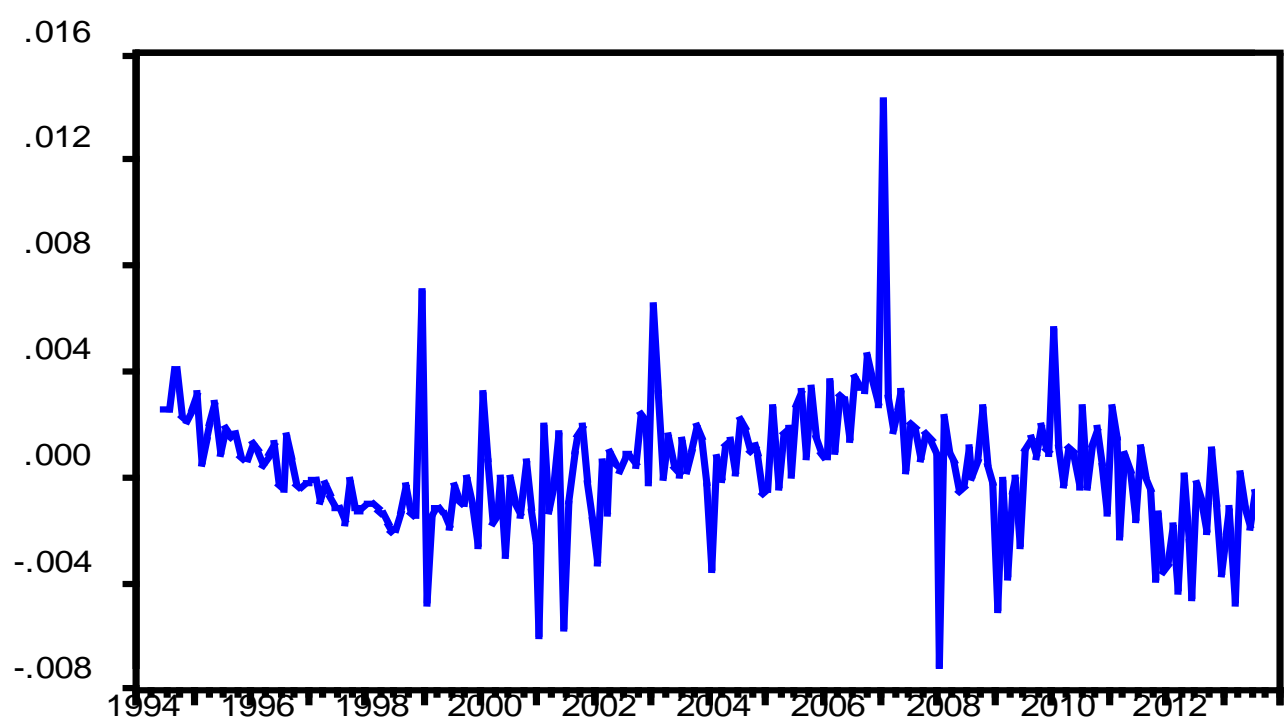

The ARDL Short-run and Long-run Cointegration Test Results: In table 10, the estimation results show that in the short-run all the explanatory variables are statistically significant at $5 \%$, hence, there is a strong evidence of short-run impact of monetary policy on industrial output production. These have shown that both the monetary variables and the control variable are major drivers of industrial output production in China. All the short-run coefficient estimates show the dynamic adjustment of all the variables as indicated by Dritsakis (2011). However, apart from inflation rates (prices), all the long-run coefficients in the model have an insignificant impact on industrial production. This means that the analysis does not reveal the long-run impact of monetary policy on industrial output production. Nonetheless, the long-run impact of prices (control variable) on industrial output production indicate that an increase in the general price level will lead to an increase in industrial output production both in the short-run as well as in the long-run. This is consistent with economic theory and empirical evidence that prices stimulate industrial output production (see López-Villavicencio and Mignon, 2011).

The ARDL Error Correction Model (ECM): A negative and significant coefficient of ECM is needed for a longrun cointegration equilibrium to be established. The ECM coefficient shows how quickly or slowly (speed of adjustment) the variables return to long-run equilibrium. However, in table 11, the coefficient estimate of the ECM is negative but statistically insignificant. The negative coefficient sign of the ECM(-1) shows that there was disequilibrium in the past and the adjustment is in the right direction but the system will not revert to equilibrium. Though the error is corrected in the present but not significantly done, hence, no convergence of the system in the long-run. This has further confirmed the short-run impact of monetary policy on industrial output production. The ECM value of -0.162399 suggests the relatively low speed of adjustment of about $16 \%$. However, the ECM is statistically insignificant at 5\% level, indicating that no long-run equilibrium can be attained. That is, no long-run impact of monetary policy on industrial output production in China but rather a short-run impact is established. This finding is in line with Sari et al. (2008) that investigate the relationship between disaggregate energy consumption and industrial production in the united states and 
Omolade et al. (2013) that investigate the impact of monetary policy and Nigeria's economic growth. Therefore, the policies enacted by monetary authorities can have a great short-run impact on industrial sector growth in China.

Table 10: The ARDL Long-run and short-run Cointegration Testing

Dependent Variable: DLOGIP

Selected Model: ARDL $(4,1,0,1,2)$

Included observations: 235

\begin{tabular}{lllll}
\hline Short-Run Coefficients & & & & \\
\hline Variable & Coefficient & Std. Error & t-Statistic & Prob. \\
\hline DLOGIP(-1) & 0.528490 & 0.070886 & 7.455460 & 0.0000 \\
DLOGIP(-2) & 0.332433 & 0.073937 & 4.496162 & 0.0000 \\
DLOGIP(-3) & 0.160399 & 0.063439 & 2.528393 & 0.0122 \\
DLOGMS & 0.002178 & 0.006296 & 0.345924 & 0.0297 \\
DLOGIF & 0.014759 & 0.009544 & 1.546451 & 0.0234 \\
LOGEX & 0.075226 & 0.030309 & 2.481986 & 0.0138 \\
IN & -0.000052 & 0.000857 & -0.060450 & 0.0419 \\
IN(-1) & -0.001425 & 0.000869 & -1.640823 & 0.0023 \\
& & & & \\
Long-Run Coefficients & & & & \\
Variable & Coefficient & Std. Error & t-Statistic & Prob. \\
LOGMS & 0.106074 & 0.077657 & 1.365929 & 0.2133 \\
LOGIF & 0.041294 & 0.072631 & 0.568544 & 0.0102 \\
LOGEX & 0.113555 & 0.218679 & 0.519278 & 0.1941 \\
IN & -0.004217 & 0.006526 & -0.646205 & 0.1188 \\
C & 0.007061 & 0.001209 & 5.841845 & 0.0000 \\
\hline
\end{tabular}

Table 11: Error Model

\begin{tabular}{lllll}
\hline Variable & Coefficient & Std. Error & t-Statistic & Prob. \\
\hline $\operatorname{ECM}(-1)$ & -0.162399 & 0.049534 & -3.278565 & 0.2012 \\
\hline
\end{tabular}

\section{Conclusion}

In this study, the effectiveness of monetary policy and industrial sector growth was examined through a time series data analysis method in China. Monthly data between 1994 and 2013 periods was used. The empirical result has led to some revelations regarding the relationship between monetary policy and the industrial production. Firstly, the empirical findings reveal that there exists a short-run relationship between industrial sector growth (output production) and monetary policy in China during the period under review. Again, it can be deduced from the results that monetary policy variables (interest rates, money supply and exchange rates) have a significant impact on the industrial sector growth in China. It can therefore be concluded that the impact of the monetary policy on China's economy is increasingly becoming very important and that it is important for policymakers to pay more attentions to policy instruments in their attempt to correcting and guiding the economy in stimulating industrial sector growth. However, only price (control variable) is statistically significant in the long-run. Hence, no long-run impact of monetary policy on industrial output production in China. Finally, as a policy guideline and recommendation, there should be balanced approach in the use of instruments to achieve certain targets or goals and to stimulate the industrial sector growth. The balanced approach is needed because, a sound economic policy is important for industrial sector development while poor policy results in a nexus of constraints from which escape may be difficult (or impossible) and hence, have adverse effects on industrial sector growth. The monetary authority should devise strategies to ensure the long-run stability of exchange rates by allowing the market forces to completely determine the value of Renminbi rather than the fixed exchange rate system and the managed floating exchange rate system currently adopted in the country. There should also be long-run stability of the 
interest rates in order to allow investors to forecast and make investment decisions that can boost industrial output production in the country. Finally, the money supply should also be adequately managed and there should be price stability in the economy.

Acknowledgements: This paper was presented at the Macroeconomics Working Group (MWG) seminar during which many useful discussions took place. We would want to thank all the members for their contributions, which have helped us to improve upon the article.

\section{References}

Ali, S., Irum, S. \& Ali, A. (2008). Whether Fiscal Stance or Monetary Policy is Effective for Economic Growth in Case of South Asian Countries? The Pakistan Development Review, 3, 791-799.

Bernanke, B. S., Boivin, J. \& Eliasz, P. (2005). Measuring the effects of monetary policy: a factor-augmented vector autoregressive (FAVAR) approach. The Quarterly Journal of Economics, 120(1), 387-422.

Brooks, C. (2002). Introductory Econometrics for Finance Cambridge University Press. United Kingdom.

Christiano, L., Eichenbaum, M. \& Evans, C. (1996). The Effects of Monetary Policy Shocks: Evidence from the Flow of Funds. The Review of Economics and Statistics, 78(1), 16-34.

Chuku, C. (2009). Measuring the effects of monetary policy innovations in Nigeria: A structural vector autoregressive (SVAR) approach. African Journal of Accounting, Economics, Finance and Banking Research, 5(5).

Demetriades, P. \& Fielding, D. (2012). Information, institutions, and banking sector development in West Africa. Economic Inquiry, 50(3), 739-753.

Dong, Z. (2012). Impact of Monetary Policy on Economic Growth in China. Advances in Information Sciences \& Service Sciences, 4(16).

Dritsakis, N. (2011). Demand for Money in Hungary: An ARDL Approach. Review of Economics and Finance, 5, $1-28$.

Erik Hjalmarsson \& PärÖsterholm, T. (2007). Testing for Cointegration Using the Johansen Methodology when Variables are Near-Integrated. An IMF Working Paper WP/07/141.

Fasanya, I. O., Onakoya, A. B. \& Agboluaje, M. A. (2013). Does monetary policy influence economic growth in Nigeria? Asian Economic and Financial Review, 3(5), 635.

Fernald, J. G., Spiegel, M. M. \& Swanson, E. T. (2014). Monetary policy effectiveness in China: Evidence from a FAVAR model. Journal of International Money and Finance, 49, 83-103.

Frimpong, P. B. (2012). Population Health and Economic Growth: Panel Cointegration Analysis in SubSaharan Africa. Master's thesis at Lund University.

Geiger, M. (2008). Instruments of monetary policy in China and their effectiveness: 1994-2006. UN Discussion Paper Number 187.

Giles, D. (2013). Econometrics Beat: Dave Giles' Blog: ARDL Models - Part I 2.

Gong, M. \& Li, W. (2006). The Effectiveness of Monetary Policy in China During 1993-2004. Available online at cmr.xmu.edu.cn/photos/20061220124741307.doc

Gujarati, D. (2004). Basic Econometrics, 4th Edition. The McGraw-Hill Companies.

Ishibashi, S. (2012). The Segmentation of Loan Interest Rates by Regional Financial Institutions: A Panel Cointegration Analysis. International Review of Business Research Papers, 8(5), 95-110.

Katircioglu, S. T. (2009). Revisiting the tourism-led-growth hypothesis for Turkey using the bounds test and Johansen approach for cointegration. Tourism Management, 30(1), 17-20.

Kim, S. (1999). Do monetary policy shocks matter in the G-7 countries? Using common identifying assumptions about monetary policy across countries. Journal of international economics, 48(2), 387412.

Kouakou, A. K. (2011). Economic growth and electricity consumption in Cote d'Ivoire: Evidence from time series analysis. Energy Policy, 39(6), 3638-3644.

Kutu, A. A. \& Ngalawa, H. (2016). Monetary Policy Shocks and Industrial Sector Performance in South Africa. Journal of Economics and Behavioral Studies, 8(3), 26-40.

Kutu, A. A., Akinola, G. W. \& Nzimande, N. P. (2016). Monetary Policy and Output Growth Forecasting in a SVAR Perspective. International Journal of Economics and Finance, 8(7), 71.

Liao, W. \& Tapsoba, S. (2014). China's Monetary Policy and Interest Rate Liberalization: Lessons from International Experiences. IMF Working Paper No. 14/75. 
Liu, W., Li, S. R. \& Li, S. Y. (2002). Monetary Expansion, Economic Growth and System Innovation of Capital Market. Economic Research, 1, 27-32.

López-Villavicencio, A. \& Mignon, V. (2011). On the impact of inflation on output growth: Does the level of inflation matter? Journal of Macroeconomics, 33(3), 455-464.

Moon, H. R. \& Perron, B. (2004). Testing for a unit root in panels with dynamic factors. Journal of econometrics, 122(1), 81-126.

Muneer, S. \& Rehman, K. U. (2012). Materialization of Behavioral Finance and Behavioral Portfolio Theory: A Brief Review. Journal of Economics and Behavioral Studies, 4(8), 431-435

Muneer, S., Butt, B. Z. \& Rehman, K. U. (2011). A Multifactor Model of Banking Industry Stock Returns: An Emerging Market Perspective. Information Management and Business Review, 2(6), 267-275

Nagel, A. \& Parker, J. (2003). Empirical macroeconomics: The effects of monetary policy. Gold-Hammer Collaborative Research at Reed College. Available at http://academic.reed.edu/economics/course_pages/341_f06/Monetary_Policy_Chapter.pdf.

Narayan, P. K. (2005). The saving and investment nexus for China: evidence from cointegration tests. Applied economics, 37(17), 1979-1990.

Naudé, W., Szirmai, A. \& Haraguchi, N. (2015). Structural Change and Industrial Development in the BRICS. Published by Oxford University Press, Oxford-USA.

Ncube, M. \& Ndou, E. (2011). Monetary policy transmission, house prices and consumer spending in South Africa: an SVAR approach. African Development Bank. Working Paper, 133, 1-48.

Ngalawa, H. \& Viegi, N. (2011). Dynamic effects of monetary policy shocks in Malawi. South African Journal of Economics, 79(3), 224-250.

Omolade, A., Ashamu, S. O. \& Morakinyo, A. (2013). Monetary Policy and Nigeria's Economic Growth. IOSR Journal of Economics and Finance (IOSR-JEF), 2, 56-63.

Omoniyi, L. G. \& Olawale, A. N. (2015). An Application of ARDL Bounds Testing Procedure to the Estimation of Level Relationship between Exchange Rate, Crude Oil Price and Inflation Rate in Nigeria. International Journal of Statistics and Applications, 5(2), 81-90.

Ozturk, I. \& Acaravci, A. (2011). Electricity consumption and real GDP causality nexus: Evidence from ARDL bounds testing approach for 11 MENA countries. Applied Energy, 88(8), 2885-2892.

Ozturk, I. \& Acaravci, A. (2013). The long-run and causal analysis of energy, growth, openness and financial development on carbon emissions in Turkey. Energy Economics, 36, 262-267.

Pesaran, M. H., Shin, Y. \& Smith, R. J. (2001). Bounds testing approaches to the analysis of level relationships. Journal of applied econometrics, 16(3), 289-326.

Ping, X. (2004). The Analysis of China's Monetary Policy in 1998-2002 [J]. Journal of Finance, 8, 001.

Precious, C. \& Makhetha-Kosi, P. (2014). Impact of Monetary Policy on Economic Growth: A Case Study of South Africa. Mediterranean Journal of Social Sciences, 5(15), 76.

Rafindadi, A. A. \& Yosuf, Z. (2013). An application of panel ARDL in analyzing the dynamics of financial development and economic growth in 38 Sub-Saharan African continents. In Proceeding-Kuala Lumpur International Business, Economics and Law Conference.

Robinson, P. M. \& Marinucci, D. (2003). Fractional Cointegration. Time Series with Long Memory, 334.

Saibu, M. O. \& Apanisile, O. T. (2013). A bound test analysis of the effects of global economic shocks on Nigerian economy: The role of fiscal and monetary policies (1960-2011). Australian Journal of Business and Management Research, 2(12), 58-68.

Sari, R., Ewing, B. T. \& Soytas, U. (2008). The relationship between disaggregate energy consumption and industrial production in the United States: an ARDL approach. Energy Economics, 30(5), 2302-2313.

Sharifi-Renani, H. O. S. E. I. N. (2010). A structural VAR approach of monetary policy in Iran. In International Conference on Applied Economics-ICOAE (p. 631).

Sun, R. (2013). Does monetary policy matter in China? A narrative approach. China Economic Review, 26, 5674.

Uhlig, H. (2005). What are the effects of monetary policy on output? Results from an agnostic identification procedure. Journal of Monetary Economics, 52(2), 381-419.

Zhou, H. (2015). Effectiveness Study of Chinese Monetary Policy Regulation on Economic Growth and Inflation. In China's Monetary Policy Regulation and Financial Risk Prevention (pp. 19-32). Springer Berlin Heidelberg. 